\title{
Kinerja Perusahaan Berdasarkan Pertumbuhan Investasi dan Potensi Kebangkrutan Sub Sektor Perkebunan di Bursa Efek Indonesia Periode 2014 - 2017
}

\author{
${ }^{1}$ Zamzami, ${ }^{2}$ Osrita Hapsara, ${ }^{3}$ Yunan Surono \\ ${ }^{1}$ Mahasiswa Magister Manajemen Universitas Batanghari Jambi, Indonesia \\ ${ }^{2,3}$ Dosen Fakultas Ekonomi, Universitas Batanghari Jambi, Indonesia
}

\begin{abstract}
This research aims to prove the stock sub group of the plantation sector has a positive value of the company (investment growth) if measured using model Tobin's q, and potential bankruptcy if measured using models Altman's Z-score first, Altman's Z-score and the Z-Altman's revision of the score as well as modifications to get the stocks that had the best performance based on the model. The sample in this study using census methods, namely the entire company group issuers shares sub plantation sector during the four-year period, starting from the observation of the year 2014-2017 recorded as many as 16 corporate issuers in Indonesia stock exchange, This form of research is research eksplanatoris. The results showed that the company's performance based on investment growth with model Tobin's $q$ on sub plantation sector was by $20 \%$ by the year 2014, by the year 2015 amounting to $13.33 \%$ and in the year 2016 amounting to $13.33 \%$ and the year 2017 of 26.67\%. Group company shares sub plantation sector which has the best performance based on the model of the Altman Z-score First for potential bankruptcy was able to note that in 2014, based on code by issuers SSMS, LSIP and AALI. In the year 2015, 2016 and 2017 which had the most improved performance is SSMS and LSIP. Group company shares sub plantation sector which has the best performance based on the model of the Altman Z-score for potential Revision of bankruptcy, it can be noted that in the year 2014, with code ANJT, LSIP issuers and SSMS. In the year 2015, 2016 and 2017 which had the most improved performance is LSIP. Group company shares sub plantation sector which has the best performance based on the model of the Altman Z-score for potential bankruptcy Modification is the year 2014, with code issuers LSIP, SSMS, ANJT, AALI, SGRO and GOLL. In the year 2015, the stocks that have the most excellent performance namely LSIP, ANJT, AALI and SSMS. In the year 2016, the stocks that have the most excellent performance namely LSIP, AALI, ANJT, PALM, SSMS, SMAR and SIMP and the year 2017 which had the most improved performance is LSIP, AALI, ANJT, SSMS and SMAR.
\end{abstract}

Keywords: Investment growth, bankruptcy model, Model Tobin's q, Altman Z-score first model, revisions model, and modification model

\section{PENDAHULUAN}

Indikator ekonomi yang digunakan untuk mengukur kinerja dalam bisnis dapat dilihat dari beberapa aspek, penggunaan indikator sebagai alat ukur dari suatu variabel sangat diperlukan, sebagai upaya untuk memudahkan dalam memahami maknanya. Tidak mudah untuk menentukan suatu indikator sebagai pengukur variabel, karena indikator tersebut harus mampu merepresentasikan variabel yang akan diukur secara tepat, sehingga secara ilmiah bisa diterima dan dipertanggungjawabkan kebenarannya sebagai indikator yang tepat untuk mengukur variabel. (Sudiyatno dan Elen, 2010). Salah satu indikator perusahaan memiliki kinerja yang baik dapat dilihat dari aspek keuangan. Laporan keuangan yang diterbitkan oleh perusahaan merupakan salah satu sumber informasi mengenai posisi keuangan perusahaan, kinerja serta perubahan posisi keuangan yang sangat berguna untuk mendukung pengambilan keputusan yang tepat sehingga diperlukan alat analisis yang menghubungkan beberapa rasio sekaligus untuk menilai kondisi keuangan perusahaan dan diharapkan mampu meningkatkan nilai perusahaan. Tujuan utama perusahaan adalah meningkatkan nilai perusahaan melalui peningkatan kemakmuran pemilik atau pemegang saham. (Adisetiawan, 2018)

Nilai perusahaan dapat dinilai melalui rasio rasio keuangan seperti likuiditas, profitabilitas, aktifitas, leverage, kebijakan deviden, rasio pasar dan Tobin's q yang digunakan untuk menilai prospek pertumbuhan investasi. Rasio-rasio tersebut dapat menjadi indikasi bagi manajemen mengenai penilaian investor terhadap kinerja manajemen dimasa lalu dan prospeknya dimasa depan. Nilai perusahaan pada dasarnya merupakan gambaran kinerja perusahaan yang terefleksikan pada harga saham yang ada dipasar, karena harga pasar saham mencerminkan penilaian investor atas keseluruhan ekuitas yang dimiliki, sehingga nilai perusahaan 
merupakan nilai pasar. Hal ini disebabkan karena nilai perusahaan dapat memberikan keuntungan atau kemakmuran bagi para pemiliknya secara maksimum apabila harga saham perusahaan tersebut meningkat, semakin tinggi peningkatan harga tersebut maka akan semakin tinggi pula minat investor untuk memilikinya sehingga akan berdampak pada peningkatan harga saham tersebut sehingga nilai perusahaan juga akan meningkat. Nilai perusahaan dapat dicapai dengan maksimum jika para pemegang saham menyerahkan urusan pengelolaan perusahaan pada orang orang yang berkompeten pada bidangnya seperti manajer atau komisaris.

Selain variabel-variabel yang telah disebutkan diatas, maka perlu juga bagi investor untuk memahami pentingnya potensi dari kegagalan investasi yang sering dikenal sebagai risiko. Variabel dari model ini diambil dari neraca dan laporan laba/rugi perusahaan, seperti yang ada pada model Altman's Zscore, yang sering di jadikan sebagai bahan dan acuan bagi para peneliti, akademisi maupun para analis untuk melihat potensi kebangkrutan bagi suatu perusahaan. Analisa diskriminan tersebut merupakan suatu analisis teknik statistik yang mengidentifikasikan beberapa macam rasio keuangan yang dirasakan memiliki nilai terpenting dalam mempengaruhi suatu kinerja tertentu maupun suatu keadaan, dan mengembangkannya ke dalam suatu model dengan maksud guna memudahkan dalam menarik kesimpulan dari suatu keadaaan. Analisis diskriminan ini kemudian menghasilkan beberapa pengelompokan yang bersifat mendasarkan teori pada kenyataan yang sebenarnya. (Adisetiawan, 2018)

Nilai Z-score ini diyakini akan mampu melihat kondisi keuangan perusahaan secara baik, sehingga dapat di jadikan sebagai antisipasi sedini mungkin (signal early warning system) terhadap kinerja dan kesehatan keuangan perusahaan yang dipengaruhi oleh beberapa indikator-indikator yang mampu menggambarkan kegagalan keuangan perusahaan. Altman's Z-score merupakan indikator untuk mengukur potensi kebangkrutan suatu perusahaan. Nilai Z-score diperoleh 5 unsur rasio; working capital to total assets, retairned earning to total assets, earning before interest and tax to total assets, market value to book value of total debt, and total revenue to total assets. Rasio-rasio tersebut menggambarkan rasio dari kemampuan manajemen di dalam mengelola aktiva perusahaan, sehingga Altman's Z-score dapat juga digunakan untuk mengukur kinerja perusahaan, yaitu dari sisi potensi kebangkrutan suatu perusahaan.

Penelitian sebelumnya yang dilakukan Ramdani dan Lukviarman (2009), dengan menganalisis perbandingan analisis model kebangkrutan menggunakan model altman pertama, altman revisi dan altman modifikasi dengan ukuran dan umur perusahaan sebagai variabel penjelas pada perusahaan manufaktur di Bursa Efek Indonesia. Demikian juga penelitian yang dilakukan oleh Sudiyatno dan Ellen Puspitasari (2010), mengenai Tobin,s q dan Altman's Z-score sebagai indikator pengukuran kinerja perusahaan. Peneltian tersebut mencoba untuk menganalisis kinerja perusahaaan berdasarkan multiple analysis discriminant, termasuk juga penelitian yang dilakukan Kokyung (2014) dan Lazuardy (2016), yang menggunakan Z-score Altman, Springate dan Tobin's q.

Penelitian ini mencoba untuk mengaplikasikan potensi pertumbuhan investasi dan potensi kebangkrutan pada perusahaan emiten sub sektor perkebunan sebagai akibat adanya kebijakan pemerintah yang sedang menggodok peraturan yang mewajibkan penggunaan solar bercampur minyak kelapa sawit sebesar 20\% (B20). Kebijakan ini akan berlaku pada 1 September 2018. Kebijakan ini ditempuh untuk memangkas impor minyak diesel, dalam rangka mengurangi defisit transaksi berjalan (current account deficit). Apabila kebijakan ini sudah terealisasi, maka konsumsi minyak sawit mentah atau crude palm oil (CPO) domestik Indonesia akan meningkat pesat dan mampu menjadi sentimen positif bagi emiten-emiten sektor perkebunan. (Kontan.co.id)

\section{Landasan Teori \\ Investasi}

Tandelilin (2001) berpendapat investasi merupakan komitmen atas sejumlah dana atau sumber daya lainnya yang dilakukan pada saat ini, dengan tujuan memperoleh sejumlah keuntungan dimasa datang.

\section{Pertumbuhan Investasi (Tobin's Q)}

Pertumbuhan investasi merupakan suatu cara yang mengukur seberapa besar kemampuan perusahaan dalam mempertahankan posisinya didalam industri dan dalam perkembangan ekonomi secara umum. 
Pertumbuhan investasi dapat dilihat dari beberapa aspek seperti dari segi sales (penjualan), earning after tax (EAT), laba perlembar saham, deviden perlembar saham, harga pasar perlembar saham maupun tobin q. Tobin's q mengindikasikan kinerja pasar perusahaan dan akan diukur dengan menggunakan nilai pasar saham perusahaan yang beredar di pasar modal. Apabila suatu perusahaan dikelola dengan baik dampaknya akan tercermin pada harga saham yang lebih baik pula. Pada pasar yang efisien harga saham akan merefleksikan informasi yang tersedia di bursa. Tobin's q sebagai salah satu alat penilaian aset sudah banyak digunakan dalam penelitian untuk menentukan nilai atau kinerja perusahaan. Tobin's $q$ adalah gambaran statistik yang berfungsi sebagai proksi dari nilai perusahaan dari perspektif investor, Tobin's $q$ merupakan nilai pasar dari firm's assets dan replacement value of those assets. Secara matematis Tobin's $q$ dapat dihitung dengan formulasi rumus sebagai berikut:

$\mathrm{q}=(\mathrm{MVS}+\mathrm{MVD}) / \mathrm{RVA}$

Dimana:MVS = Market value of all outstanding stock.; MVD = Market value of all debt.; RVA = Replacement value of all production capacity.

Adapun skor interpretasi dari nilai tobin's q antara lain;

Tobin's q < 1; Menggambarkan bahwa saham dalam kondisi Undervalued. Manajemen telah gagal dalam mengelola aktiva perusahaan. Potensi pertumbuhan investasi rendah.

Tobin's q $=1$; Menggambarkan bahwa saham dalam kondisi average. Manajemen stagnan dalam mengelola aktiva. Potensi pertumbuhan investasi tidak berkembang.

Tobin's q > 1; Menggambarkan bahwa saham dalam kondisi overvalued. Manajemen berhasil dalam mengelola aktiva perusahaan. Potensi pertumbuhan investasi tinggi.

Berdasarkan penjelasan dalam interpretasi tersebut di atas, maka investor yang akan mengejar capital gain dapat mengambil keputusan untuk membeli, menahan atau menjual saham yang dimilikinya.

\section{Potensi Kebangkrutan (Financial Distress).}

Platt dan Platt (2002) dalam Fahmi (2013), mendefinisikan bahwa financial distress adalah tahap penurunan kondisi keuangan yang dialami oleh suatu perusahaan, yang terjadi sebelum terjadinya kebangkrutan ataupun likuidasi. Financial distress dimulai dengan ketidakmampuan memenuhi kewajibankewajibannya, baik bersifat jangka pendek dan jangka panjang. Financial distress adalah kondisi dimana perusahaan tidak mampu lagi melunasi kewajibannya. Ada indikasi awal dari perusahaan tersebut yang biasanya dapat dikenali lebih dini kalau laporan keuangan dianalisis secara lebih cermat dengan suatu cara tertentu, kondisi ini biasanya tidak mucul begitu saja di perusahaan. Rasio keuangan yang dapat digunakan sebagai indikasi adanya kebangkrutan di perusahaan. Menurut Dermawan (2014), Financial Distress merupakan situasi dimana aliran kas operasi sebuah perusahaan tidak cukup memuaskan kewajibankewajiban yang sekarang (misal penjualan kredit atau pengeluaran bunga) dan perusahaan dipaksa untuk melakukan tindakan korelatif. Berdasarkan uraian di atas mengenai definisi dari financial distress dapat ditarik kesimpulan bahwa financial distress merupakan tekanan keuangan yang dihadapi oleh sebuah perusahaan. Financial distress hanyalah salah satu penyebab bangkrutnya sebuah perusahaan. Namun tidak berarti semua perusahaan yang mengalami financial distress akan menjadi bangkrut.

\section{Model Altman Z-score Pertama}

Altman Z-score merupakan indikator untuk mengukur potensi kebangkrutan suatu perusahaan pada model pertama. Nilai Z-score diperoleh dari penjumlahan hasil perkalian suatu nilai konstanta tertentu masing-masing dengan 5 unsur rasio; working capital to total assets, retairned earning to total assets, earning before interest and tax to total assets, market value to book value of total debt, and total revenue to total assets. Altman menemukan lima jenis rasio keuangan yang dapat dikombinasikan untuk melihat perbedaan antara perusahaan yang bangkrut dan yang tidak bangkrut. Z-Score ditentukan dengan menggunakan rumus sebagai berikut; Ayu Suci R., (2009).

$Z$-Score $=1,2 \mathrm{X} 1+1,4 \mathrm{X} 2+3,3 \mathrm{X} 3+0,6 \mathrm{X} 4+0,999 \mathrm{X} 5$

Dimana:X1 = Working Capital to Total Assets,; X2 = Retained Earning to Total Assets,; X3 = Earning Before Interest and Taxes (EBIT) to Total Assets,; X4 = Market Value of Equity to Book Value of Total Liabilities,; X5 = Sales to Total Assets. 
Menurut Altman, terdapat angka-angka cut off nilai $\mathrm{Z}$ yang dapat menjelaskan apakah perusahaan akan mengalami kegagalan atau tidak pada masa mendatang dan ia membaginya ke dalam tiga kategori, yaitu:

- Jika nilai $\mathrm{Z}<1,8$ maka termasuk perusahaan yang bangkrut.

- Jika nilai 1,8 $<\mathrm{Z}<2,99$ maka termasuk grey area (tidak dapat ditentukan apakah perusahaan sehat ataupun mengalami kebangkrutan).

- Jika nilai Z > 2,99 maka termasuk perusahaan yang tidak bangkrut.

\section{Model Altman Z-score Revisi.}

Model prediksi kebangkrutan sudah dikembangkan ke beberapa negara. Altman melakukan survei model-model yang dikembangkan di Amerika Serikat, Jepang, Jerman, Swiss, Australia, Inggris, Irlandia, Kanada, Belanda, dan Perancis. Salah satu masalah yang bisa di bahas adalah apakah ada kesamaan rasio keuangan yang bisa dipakai untuk prediksi kebangkrutan untuk semua negara, ataukah mempunyai kekhususan. Model revisi yang dilakukan Altman merupakan penyesuaian yang dilakukan agar model prediksi kebangkrutan ini tidak hanya untuk perusahaan manufaktur yang go public melainkan juga untuk diaplikasikan pada perusahaan-perusahaan di sektor swasta. Masalah lain yang perlu dipertimbangkan adalah banyak perusahaan yang tidak go public, dan dengan demikian tidak mempunyai nilai pasar. Untuk beberapa negara seperti Indonesia, perusahaan yang tidak go public masih cukup banyak dengan porsi yang relatif lebih banyak.

Altman kemudian mengembangkan model alternatif dengan menggantikan variabel X4 (Nilai pasar saham preferen dan biasa/nilai buku total). Dengan cara demikian model tersebut dipakai baik untuk perusahaan yang go public maupun yang tidak go public. Model Altman (1983), adalah dengan persamaan berikut:

$Z^{\prime}=0,717 \mathrm{X} 1+0,847 \mathrm{X} 2+3,107 \mathrm{X} 3+0,420 \mathrm{X} 4+0,998 \mathrm{X} 5$

Dimana; Z' = bankrupcy index Revised,; X1 = (Aktiva Lancar- Utang Lancar)/Total Aktiva,; X2 = Laba yang Ditahan/Total Aset,; X3 = Laba Sebelum Bunga dan Pajak/Total Aset,; X4 = Nilai buku saham biasa dan preferen/Nilai buku total utang,; X5 = Penjualan/Total Aset.

yaitu:

Kategori perusahaan yang sehat dan bangkrut didasarkan pada nilai Z-Score metode Altman revisi

- Nilai Z' < 1,23 maka termasuk perusahaan yang bangkrut.

- Nilai 1,23 < Z' < 2,9 maka termasuk grey area (tidak dapat ditentukan apakah perusahaan sehat atau mengalami kebangkrutan).

- Nilai Z' > 2,9 maka termasuk perusahaan tidak bangkrut.

\section{Altman Model Modifikasi}

Waktu yang terus berjalan dan terus berkembang maka perlu penyesuaian terhadap berbagai jenis perusahaan yang ada, Altman kemudian memodifikasi modelnya agar dapat diterapkan pada semua jenis perusahaan, sepeti perusahaan manufaktur, non manufaktur, dan perusahaan penerbit obligasi di negara berkembang (emerging market). Dalam Z-score modifikasi tersebut, Altman mengeliminasi variable X5 (sales/total asset.) karena rasio ini sangat bervariatif pada industri dengan ukuran asset yang berbeda-beda. Persamaan Z-Score yang di Modifikasi Altman dkk (1995), menggunakan persamaan berikut:

$Z "=6,56 \mathrm{X} 1+3,26 \mathrm{X} 2+6,72 \mathrm{X} 3+1,05 \mathrm{X} 4$

Dimana $=\mathrm{Z} "=$ bankrupcy index modified, $; \mathrm{X} 1=$ working capital/total asset $; \mathrm{X} 2=$ retained earnings/total asset,; X3 = earning before interest and taxes/total asset,; X4 = book value of equity/book value of total debt.

Kategori perusahaan yang sehat dan bangkrut didasarkan pada nilai Z-score model Altman Modifikasi yaitu:

- Jika nilai Z" < 1,1 maka termasuk perusahaan yang bangkrut.

- Jika nilai $1,1<\mathrm{Z}$ " $<2,6$ maka termasuk grey area (tidak dapat ditentukan apakah perusahaan sehat ataupun mengalami kebangkrutan).

- Jika nilai Z"> 2,6 maka termasuk perusahaan yang tidak bangkrut. 


\section{HASIL DAN PEMBAHASAN}

Hasil perhitungan dengan menggunakan analisis diskriminan model Tobin's $q$ dan model Altman ZScore (Model Pertama, Model Revisi dan Model Modifikasi) dalam memprediksi pertumbuhan investasi dan potensi kebangkrutan suatu perusahaan sub sektor perkebunan yang terdaftar di Bursa Efek Indonesia, sebanyak 15 perusahaan emiten diperoleh hasil seperti pada tabel 1, tabel 2, tabel 3 dan tabel 4 berikut;

Tabel 1.

Kelompok Saham Berdasarkan Perhitungan Model Tobin's q 2014 - 2017.

\begin{tabular}{|c|c|c|c|c|c|c|c|c|c|}
\hline \multicolumn{10}{|c|}{ Model Tobin's q } \\
\hline No & Perusahaan & 2014 & keterangan & 2015 & keterangan & 2016 & keterangan & 2017 & keterangan \\
\hline & PT. Sawit Sumbermas Sarana Tbk (SSMS) & 5,0168 & Overvalue & 4,9717 & Overvalue & 4,0877 & Overvalue & 2,4171 & Overvalue \\
\hline & PT. London Sumatra Indonesia, Tbk. (LSIP) & 1,9323 & Overvalue & 1,1844 & Overvalue & 1,0261 & Overvalue & 1,3575 & Overvalue \\
\hline & PT. Eagle High Plantation, Tbk. (BWPT) & 1,0608 & Overvalue & 0,9958 & Undervalue & 0,9779 & Undervalue & 1,1432 & Overvalue \\
\hline & PT. Astra Agro Lestari, Tbk. (AALI) & 0,9450 & Undervalue & 0,9860 & Undervalue & 0,9456 & Undervalue & 1,0501 & Overvalue \\
\hline & PT. Dharma Satya Nusantara, Tbk. (DSNG) & 0,8174 & Undervalue & 0,8132 & Undervalue & 0,8111 & Undervalue & 0,7994 & Undervalue \\
\hline & PT. Bakrie Sumatera Plantations Tbk & 0,7826 & Undervalue & 0,8075 & Undervalue & 0,8088 & Undervalue & 0,7970 & Undervalue \\
\hline & PT. Tunas Baru Lampung Tbk (TBLA) & 0,7405 & Undervalue & 0,7138 & Undervalue & 0,7402 & Undervalue & 0,7085 & Undervalue \\
\hline & PT. Smart Tbk (SMAR) & 0,6271 & Undervalue & 0,6819 & Undervalue & 0,6983 & Undervalue & 0,6544 & Undervalue \\
\hline & PT. Provident Agro Tbk (PALM) & 0,6156 & Undervalue & 0,6482 & Undervalue & 0,6964 & Undervalue & 0,6485 & Undervalue \\
\hline & PT. Jaya Agra Wattie, Tbk. (JAWA) & 0,5897 & Undervalue & 0,6295 & Undervalue & 0,6909 & Undervalue & 0,6043 & Undervalue \\
\hline & PT. Sampoerna Agro Tbk (SGR0) & 0,5732 & Undervalue & 0,6009 & Undervalue & 0,6109 & Undervalue & 0,5645 & Undervalue \\
\hline & PT. Gozco Plantations, Tbk. (GZCO) & 0,5616 & Undervalue & 0,5967 & Undervalue & 0,6100 & Undervalue & 0,4994 & Undervalue \\
\hline & PT. Golden Plantation, Tbk. (GOL) & 0,5455 & Undervalue & 0,5101 & Undervalue & 0,4975 & Undervalue & 0,4816 & Undervalue \\
\hline & PT. Salim Ivomas Pratama Tbk (SIMP) & 0,5416 & Undervalue & 0,4822 & Undervalue & 0,4037 & Undervalue & 0,4555 & Undervalue \\
\hline & PT. Austindo Nusantara Jaya, Tbk.(ANJT) & 0,1609 & Undervalue & 0,3155 & Undervalue & 0,3511 & Undervalue & 0,3160 & Undervalue \\
\hline
\end{tabular}

Sumber; data olahan

Hasil penelitian pada tabel 1 diatas, merupakan hasil kelompok saham perusahaan sub sektor perkebunan tersebut yang mempunyai nilai perusahaan dengan nilai positif, yang berarti mempunyai pertumbuhan investasi jika diukur dengan menggunakan Tobin's q, dapat diketahui bahwa hasil kelompok saham perusahaan sub sektor perkebunan tersebut yang mempunyai nilai di atas 1 yang berarti mempunyai pertumbuhan investasi dan yang mempunyai nilai kurang dari 1 yang berarti mempunyai pertumbuhan investasi rendah.

Tabel 2

Kelompok Saham Berdasarkan Perhitungan Model Altman Z-score Pertama dari Tahun 2014 -2017.

\begin{tabular}{|c|c|c|c|c|c|c|c|c|c|}
\hline \multicolumn{10}{|c|}{ Model Altman Z-score Pertama } \\
\hline No & Perusahaan & 2014 & keterangan & 2015 & keterangan & 2016 & keterangan & 2017 & keterangan \\
\hline & PT. Sawit Sumbermas Sarana Tbk (SSMS) & 13,47251 & Tidak Bangkrut & 5,75406 & Tidak Bangkrut & 5,35201 & Tidak Bangkrut & 3,91440 & Tidak Bangkrut \\
\hline 2 & PT. London Sumatra Indonesia, Tbk. (LSIP) & 8,42675 & Tidak Bangkrut & 5,32159 & \begin{tabular}{|l|} 
Tidak Bangkrut \\
\end{tabular} & 4,31219 & Tidak Bangkrut & 3,42347 & Tidak Bangkrut \\
\hline 3 & PT. Astra Agro Lestari, Tbk. (AALI) & 3,18484 & Tidak Bangkrut & 1,89461 & Abu-abu & 2,52942 & Abu-abu & 2,38475 & Abu-abu \\
\hline 4 & PT. Smart Tbk (SMAR) & 2,21558 & Abu-abu & 1,81478 & Abu-abu & 1,85777 & Abu-abu & 2,03650 & Abu-abu \\
\hline 5 & PT. Dharma Satya Nusantara, Tbk. (DSNG) & 1,53843 & FD & 1,34876 & FD & 1,15694 & FD & 1,52147 & FD \\
\hline 6 & PT. Austindo Nusantara Jaya, Tbk.(ANJT) & 1,52237 & FD & 1,12739 & FD & 1,06744 & FD & 1,44996 & FD \\
\hline 7 & PT. Sampoerna Agro Tbk (SGRO) & 1,51709 & FD & 1,12664 & FD & 1,04444 & FD & 1,28899 & FD \\
\hline 8 & PT. Tunas Baru Lampung Tbk (TBLA) & 1,47518 & FD & 0,94597 & FD & 1,00262 & FD & 1,17083 & FD \\
\hline 9 & PT. Salim Ivomas Pratama Tbk (SIMP) & 1,12611 & FD & 0,90456 & FD & 0,93696 & FD & 1,01663 & FD \\
\hline 10 & PT. Eagle High Plantation, Tbk. (BWPT) & 0,59902 & FD & 0,38781 & FD & 0,88802 & FD & 0,81064 & FD \\
\hline 11 & PT. Gozco Plantations, Tbk. (GZCO) & 0,54685 & FD & 0,33428 & FD & 0,32972 & FD & 0,47527 & FD \\
\hline 12 & PT. Jaya Agra Wattie, Tbk. (JAWA) & 0,47185 & FD & 0,21570 & FD & 0,28144 & FD & $(0,08092)$ & FD \\
\hline 13 & PT. Golden Plantation, Tbk. (GOLL) & 0,40854 & FD & 0,03578 & FD & $(0,10214)$ & FD & $(0,09330)$ & FD \\
\hline 14 & PT. Provident Agro Tbk (PALM) & 0,28559 & FD & $(0,09157)$ & FD & $(0,96642)$ & FD & $(0,19760)$ & FD \\
\hline 15 & PT. Bakrie Sumatera Plantations Tbk & $(0,46464)$ & FD & $(0,84075)$ & FD & $(1,24457)$ & FD & $(1,74939)$ & FD \\
\hline
\end{tabular}

Sumber; data olahan 
Hasil penelitian seperti pada tabel 2 diatas, merupakan hasil kelompok saham perusahaan sub sektor perkebunan yang mempunyai potensi kebangkrutan atau tekanan keuangan (financial distress/FD) dengan model Altman Z-score Pertama, yang mempunyai potensi kebangkrutan atau tekanan keuangan (financial distress)

Tabel 3

Kelompok saham berdasarkan perhitungan Model Altman Z-score Revisi dari tahun 2014-2017

\begin{tabular}{|c|c|c|c|c|c|c|c|c|c|}
\hline \multicolumn{10}{|c|}{ Model Altman Z-score Revisi } \\
\hline No & Perusahaan & 2014 & keterangan & 2015 & keterangan & 2016 & keterangan & 2017 & keterangan \\
\hline & PT. London Sumatra Indonesia, Tbk. (LSIP) & 3,70635 & Tidak Bangkrut & 3,38919 & Tidak Bangkrut & 3,04624 & Tidak Bangkrut & 3,58882 & Tidak Bangkrut \\
\hline & PT. Austindo Nusantara Jaya, Tbk.(ANJT) & 3,42678 & Tidak Bangkrut & 1,86412 & Abu-abu & 2,40638 & Abu-abu & 2,77462 & Abu-abu \\
\hline & PT. Sawit Sumbermas Sarana Tbk (SSMS) & 3,07422 & Tidak Bangkrut & 1,84004 & Abu-abu & 1,88902 & Abu-abu & 2,10939 & Abu-abu \\
\hline & PT. Astra Agro Lestari, Tbk. (AALI) & 2,64127 & Abu-abu & 1,65671 & Abu-abu & 1,68301 & Abu-abu & 2,06668 & Abu-abu \\
\hline & PT. Smart Tbk (SMAR) & 2,27504 & Abu-abu & 1,22661 & $\mathrm{FD}$ & 1,40323 & Abu-abu & 1,48290 & Abu-abu \\
\hline & PT. Sampoerna Agro Tbk (SGRO) & 1,66543 & Abu-abu & 1,22534 & FD & 1,35500 & Abu-abu & 1,47611 & Abu-abu \\
\hline & PT. Tunas Baru Lampung Tbk(TBLA) & 1,47997 & Abu-abu & 1,21834 & FD & 1,32960 & Abu-abu & 1,31762 & Abu-abu \\
\hline & PT. Dharma Satya Nusantara, Tbk. (DSNG) & 1,45170 & Abu-abu & 1,12649 & FD & 1,08035 & FD & 1,29960 & Abu-abu \\
\hline & PT. Salim Ivomas Pratama Tbk(SIMP) & 1,35676 & Abu-abu & 0,99993 & FD & 1,01727 & FD & 1,24827 & Abu-abu \\
\hline & PT. Gozco Plantations, Tbk. (GZCO) & 0,76165 & $\mathrm{FD}$ & 0,67896 & FD & 0,99044 & $\mathrm{FD}$ & 0,88246 & Abu-abu \\
\hline & PT. Jaya Agra Wattie, Tbk. (JAWA) & 0,71303 & FD & 0,41012 & FD & 0,36195 & FD & 0,37859 & FD \\
\hline & PT. Golden Plantation, Tbk. (GOLL) & 0,63804 & FD & 0,32820 & FD & 0,28574 & FD & 0,20832 & FD \\
\hline & PT. Provident Agro Tbk (PALM) & 0,58465 & FD & 0,31742 & FD & 0,12459 & FD & 0,13067 & FD \\
\hline & PT. Eagle High Plantation, Tbk. (BWPT) & 0,43855 & FD & 0,24860 & FD & $(0,70417)$ & FD & $(0,13594)$ & FD \\
\hline 15 & PT. Bakrie Sumatera Plantations Tbk & $(0,13149)$ & FD & $(0,44947)$ & FD & $(0,85837)$ & FD & $(1,15977)$ & FD \\
\hline
\end{tabular}

Sumber; data olahan

Hasil penelitian seperti pada tabel 3 diatas, merupakan hasil kelompok saham perusahaan sub sektor perkebunan yang mempunyai potensi kebangkrutan atau tekanan keuangan (financial distress/FD) dengan model Altman Z-score Revisi.

Tabel 4

Kelompok Saham Berdasarkan Perhitungan Model Altman Z-score Modifikasi dari Tahun 2014-2017

\begin{tabular}{|c|c|c|c|c|c|c|c|c|}
\hline \multicolumn{9}{|c|}{ Model Altman Z-score Modifikasi } \\
\hline Perusahaan & 2014 & keterangan & 2015 & keterangan & 2016 & keterangan & 2017 & keterangan \\
\hline 1 PT. London Sumatra Indonesia, Tbk. (LSIP) & 9,11096 & Tidak Bangkrut & 8,30157 & Tidak Bangkrut & 7,81476 & Tidak Bangkrut & 9,26944 & Tidak Bangkrut \\
\hline 2 PT. Sawit Sumbermas Sarana Tbk (SSMS) & 8,52573 & Tidak Bangkrut & 4,48072 & Tidak Bangkrut & 5,08162 & Tidak Bangkrut & 6,07626 & Tidak Bangkrut \\
\hline 3 PT. Austindo Nusantara Jaya, Tbk.(ANJT) & 8,39216 & Tidak Bangkrut & 2,98113 & Tidak Bangkrut & 4,27226 & Tidak Bangkrut & 5,24824 & Tidak Bangkrut \\
\hline 4 PT. Astra Agro Lestari, Tbk. (AALI) & 4,43498 & Tidak Bangkrut & 2,64305 & Tidak Bangkrut & 3,58240 & Tidak Bangkrut & 4,81531 & Tidak Bangkrut \\
\hline 5 PT. Sampoerna Agro Tbk (SGR0) & 2,83240 & Tidak Bangkrut & 2,54662 & Abu-abu & 3,06360 & Tidak Bangkrut & 2,74481 & Tidak Bangkrut \\
\hline 6 PT. Golden Plantation, Tbk. (GOLL) & 2,63007 & Tidak Bangkrut & 2,20107 & Abu-abu & 2,71340 & Tidak Bangkrut & 2,57452 & Abu-abu \\
\hline \begin{tabular}{l|l|l}
7 & PT. Salim Ivomas Pratama Tbk(SIMP) \\
\end{tabular} & 2,32786 & Abu-abu & 1,74730 & Abu-abu & 2,65795 & Tidak Bangkrut & 2,41666 & Abu-abu \\
\hline \begin{tabular}{l|l}
8 & PT. Smart Tbk (SMAR) \\
\end{tabular} & 2,28811 & Abu-abu & 1,67597 & Abu-abu & 2,37421 & Abu-abu & 2,40316 & Abu-abu \\
\hline \begin{tabular}{l|l|}
9 & PT. Dharma Satya Nusantara, Tbk. (DSNG) \\
\end{tabular} & 2,24079 & Abu-abu & 1,43384 & Abu-abu & 1,54695 & Abu-abu & 1,81680 & Abu-abu \\
\hline 10 PT. Tunas Baru Lampung Tbk(TBLA) & 1,85852 & Abu-abu & 1,32902 & Abu-abu & 1,38762 & Abu-abu & 1,37904 & Abu-abu \\
\hline \begin{tabular}{l|l|}
11 & PT. Gozco Plantations, Tbk. (GZCO) \\
\end{tabular} & 1,75216 & Abu-abu & 0,61298 & $\mathrm{FD}$ & 0,56627 & $\mathrm{FD}$ & 0,08171 & FD \\
\hline \begin{tabular}{l|l|}
12 & PT. Jaya Agra Wattie, Tbk. (JAWA) \\
\end{tabular} & 0,98098 & $\mathrm{FD}$ & 0,28139 & FD & 0,02715 & FD & $(0,37882)$ & FD \\
\hline \begin{tabular}{l|l}
13 & PT. Provident Agro Tbk (PALM) \\
\end{tabular} & 0,64605 & $\mathrm{FD}$ & 0,11452 & $\mathrm{FD}$ & $(0,63953)$ & $\mathrm{FD}$ & $(0,43810)$ & FD \\
\hline 14 PT. Eagle High Plantation, Tbk. (BWPT) & 0,31149 & FD & $(0,70874)$ & FD & $(1,95240)$ & $\mathrm{FD}$ & $(2,22031)$ & $\mathrm{FD}$ \\
\hline \begin{tabular}{l|l|}
15 & PT. Bakrie Sumatera Plantations Tbk \\
\end{tabular} & $(2,21699)$ & $\mathrm{FD}$ & $(3,35105)$ & FD & $(5,44935)$ & FD & $(7,23303)$ & FD \\
\hline
\end{tabular}

Sumber; data olahan

Kinerja Perusahaan Berdasarkan Pertumbuhan Investasi dan Potensi Kebangkrutan Sub Sektor Perkebunan di Bursa Efek Indonesia Periode $2014-2017$ 
Hasil penelitian seperti pada tabel 4 diatas, merupakan hasil kelompok saham perusahaan sub sektor perkebunan yang mempunyai potensi kebangkrutan atau tekanan keuangan (financial distress) dengan model Altman Z-score Modifikasi. Berikut merupakan ringkasan keseluruhan kinerja perusahaan berdasarkan pertumbuhan investasi dari model Tobin's $q$ seperti pada tabel berikut;

\section{Tabel 5}

Kinerja perusahaan berdasarkan Pertumbuhan investasi Model Tobin's $q$ Sub Sektor Perkebunan di BEI periode 2014-2017.

\begin{tabular}{|l|r|r|r|r|}
\hline Model & \multicolumn{2}{|c|}{$\mathbf{2 0 1 4}$} & $\mathbf{2 0 1 5}$ & \multicolumn{2}{|c|}{$\mathbf{2 0 1 6}$} & \multicolumn{2}{c|}{$\mathbf{2 0 1 7}$} \\
\hline Tobin's q & 20,00 & 13,33 & 13,33 & 26,67 \\
\hline
\end{tabular}

Sumber; data olahan

Berdasarkan tabel 5 diatas, diketahui bahwa kinerja perusahaan berdasarkan pertumbuhan investasi dengan model Tobin's $q$ pada sub sektor perkebunan adalah sebesar 20\% pada tahun 2014, pada tahun 2015 sebesar 13,33\% dan pada tahun 2016 sebesar 13,33\% serta tahun 2017 sebesar 26,67\%. Selain itu, berikut merupakan ringkasan keseluruhan kinerja perusahaan berdasarkan potensi kebangkrutan dengan model Altman Z-score Pertama, Altman Z-score Revisi dan Altman Z-score Modifikasi seperti pada tabel berikut;

\section{Tabel 6}

Kinerja perusahaan berdasarkan potensi kebangkrutan dengan model Altman Z-score Pertama, Revisi dan Modifikasi Sub Sektor Perkebunan di BEI periode 2014-2017.

\begin{tabular}{|c|c|c|c|c|c|c|c|c|c|c|}
\hline & & \multicolumn{3}{|c|}{ Altman Z-s core Pertama } & \multicolumn{3}{|c|}{ Altman Z-s core Revisi } & \multicolumn{3}{|c|}{ Altman Z-s core Modifik asii } \\
\hline No & Tahun & Sehat & Abu-abu & FD & Sehat & Abu-abu & FD & Sehat & Abu-abu & FD \\
\hline 1 & 2014 & 20,00 & 6,67 & 73,33 & 20,00 & 40,00 & 40,00 & 40,00 & 33,33 & 26,67 \\
\hline 2 & 2015 & 13,33 & 13,33 & 73,33 & 6,67 & 20,00 & 73,33 & 26,67 & 40,00 & 33,33 \\
\hline 3 & 2016 & 13,33 & 13,33 & 73,33 & 6,67 & 40,00 & 53,33 & 46,67 & 20,00 & 33,33 \\
\hline 4 & 2017 & 13,33 & 13,33 & 73,33 & 6,67 & 60,00 & 33,33 & 33,33 & 33,33 & 33,33 \\
\hline
\end{tabular}

Sumber; data olahan

Berdasarkan tabel 6 diatas, diketahui bahwa kinerja perusahaan berdasarkan

a. Potensi kebangkrutan dengan model Altman Z-score Pertama pada sub sektor perkebunan adalah pada tahun 2014 kinerja perusahaan dengan kategori sehat atau tidak bangkrut adalah sebesar 20\%, sedangkan perusahaan yang mempunyai kinerja abu-abu atau tidak dapat ditentukan apakah perusahaan sehat atau mengalami kebangkrutan adalah sebesar 6,67\%, adapun kinerja perusahaan dengan kategori bangkrut atau dalam tekanan keuangan (financial distress) adalah sebesar 73,33\%. Pada tahun 2015, 2016 dan 2017 berdasarkan model Altman Z-score Pertama, kinerja perusahaan dengan kategori sehat atau tidak bangkrut adalah sebesar 13,33\%, sedangkan perusahaan yang mempunyai kinerja abu-abu atau tidak dapat ditentukan apakah perusahaan sehat atau mengalami kebangkrutan adalah sebesar 13,33\%, adapun kinerja perusahaan dengan kategori bangkrut atau dalam tekanan keuangan (financial distress) adalah sebesar $73,33 \%$.

b. Potensi kebangkrutan dengan model Altman Z-score Revisi pada sub sektor perkebunan adalah pada tahun 2014 kinerja perusahaan dengan kategori sehat atau tidak bangkrut adalah sebesar 20\%, sedangkan perusahaan yang mempunyai kinerja abu-abu atau tidak dapat ditentukan apakah perusahaan sehat atau mengalami kebangkrutan adalah sebesar $40 \%$, adapun kinerja perusahaan dengan kategori bangkrut atau dalam tekanan keuangan (financial distress) adalah sebesar $40 \%$.

Potensi kebangkrutan dengan model Altman Z-score Revisi pada sub sektor perkebunan adalah pada tahun 2015 kinerja perusahaan dengan kategori sehat atau tidak bangkrut adalah sebesar 6,67\%, sedangkan perusahaan yang mempunyai kinerja abu-abu atau tidak dapat ditentukan apakah perusahaan sehat atau mengalami kebangkrutan adalah sebesar 20\%, adapun kinerja perusahaan dengan kategori bangkrut atau dalam tekanan keuangan (financial distress) adalah sebesar 73,33\%.

Potensi kebangkrutan dengan model Altman Z-score Revisi pada sub sektor perkebunan adalah pada tahun 2016 kinerja perusahaan dengan kategori sehat atau tidak bangkrut adalah sebesar 6,67\%, 
sedangkan perusahaan yang mempunyai kinerja abu-abu atau tidak dapat ditentukan apakah perusahaan sehat atau mengalami kebangkrutan adalah sebesar $40 \%$, adapun kinerja perusahaan dengan kategori bangkrut atau dalam tekanan keuangan (financial distress) adalah sebesar 53,33\%.

Potensi kebangkrutan dengan model Altman Z-score Revisi pada sub sektor perkebunan adalah pada tahun 2017 kinerja perusahaan dengan kategori sehat atau tidak bangkrut adalah sebesar 6,67\%, sedangkan perusahaan yang mempunyai kinerja abu-abu atau tidak dapat ditentukan apakah perusahaan sehat atau mengalami kebangkrutan adalah sebesar $60 \%$, adapun kinerja perusahaan dengan kategori bangkrut atau dalam tekanan keuangan (financial distress) adalah sebesar 33,33\%.

c. Potensi kebangkrutan dengan model Altman Z-score Modifikasi pada sub sektor perkebunan adalah pada tahun 2014 kinerja perusahaan dengan kategori sehat atau tidak bangkrut adalah sebesar 40\%, sedangkan perusahaan yang mempunyai kinerja abu-abu atau tidak dapat ditentukan apakah perusahaan sehat atau mengalami kebangkrutan adalah sebesar 33,33\%, adapun kinerja perusahaan dengan kategori bangkrut atau dalam tekanan keuangan (financial distress) adalah sebesar 26,67\%.

Potensi kebangkrutan dengan model Altman Z-score Modifikasi pada sub sektor perkebunan adalah pada tahun 2015 kinerja perusahaan dengan kategori sehat atau tidak bangkrut adalah sebesar 26,67\%, sedangkan perusahaan yang mempunyai kinerja abu-abu atau tidak dapat ditentukan apakah perusahaan sehat atau mengalami kebangkrutan adalah sebesar $40 \%$, adapun kinerja perusahaan dengan kategori bangkrut atau dalam tekanan keuangan (financial distress) adalah sebesar 33,33\%.

Potensi kebangkrutan dengan model Altman Z-score Modifikasi pada sub sektor perkebunan adalah pada tahun 2016 kinerja perusahaan dengan kategori sehat atau tidak bangkrut adalah sebesar 46,67\%, sedangkan perusahaan yang mempunyai kinerja abu-abu atau tidak dapat ditentukan apakah perusahaan sehat atau mengalami kebangkrutan adalah sebesar 20\%, adapun kinerja perusahaan dengan kategori bangkrut atau dalam tekanan keuangan (financial distress) adalah sebesar 33,33\%.

Potensi kebangkrutan dengan model Altman Z-score Modifikasi pada sub sektor perkebunan adalah pada tahun 2017 kinerja perusahaan dengan kategori sehat atau tidak bangkrut adalah sebesar 33,33\%, sedangkan perusahaan yang mempunyai kinerja abu-abu atau tidak dapat ditentukan apakah perusahaan sehat atau mengalami kebangkrutan adalah sebesar 33,33\%, adapun kinerja perusahaan dengan kategori bangkrut atau dalam tekanan keuangan (financial distress) adalah sebesar 33,33\%.

Berikut merupakan ringkasan keseluruhan kinerja perusahaan berdasarkan kelompok saham sub sektor perkebunan yang mempunyai kinerja paling baik berdasarkan model Tobin's $q$ seperti pada tabel berikut;

\section{Tabel 7}

Kinerja perusahaan berdasarkan model Tobin's $q$ Sub Sektor Perkebunan di BEI periode 2014-2017.

\begin{tabular}{|c|c|c|c|c|}
\hline \multicolumn{5}{|c|}{ Hoboin's } \\
\hline No & 2014 & 2015 & 2016 & 2017 \\
\hline 1 & $S S M M S$ & $S S M M S$ & $S S M M S$ & $S S M M S$ \\
\hline 2 & ISIIP & ISIL & ISIIP & मWM \\
\hline 3 & BWIII & BWIPI & BWIPI & TINSI \\
\hline 4 & $\Lambda \Lambda I I$ & $1 \mathrm{NS} \times$ & TINSI & $\mathbf{\Lambda} \boldsymbol{\Lambda} \Lambda$ \\
\hline 5 & DNSEC & $\Delta \Lambda I I$ & CरIII & IBIA \\
\hline$\sigma$ & TISSN & UNSTE & THI A & $<x<<$ \\
\hline 7 & IBIA & IBIA & 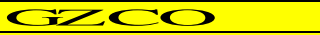 & $I S I P$ \\
\hline 8 & $S M A \Lambda I R$ & $S M A \Lambda I R$ & $\Delta \Lambda I I$ & DSINCE \\
\hline 9 & PAIMI & PAIMI & DNSE & CSCI \\
\hline 10 & $\Phi \Lambda \boldsymbol{N}$ & $\Phi \Lambda \boldsymbol{N}$ & $\boldsymbol{\top} \Lambda \boldsymbol{\Lambda}$ & $S M A \wedge I R$ \\
\hline 11 & $S<$ HiR & तरा I & $S<$ HiR & $S<$ HR \\
\hline 12 & $c<<<$ & $S<$ HR & SMIAIR & PAINI \\
\hline 13 & 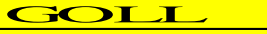 & $<<<$ & SIMIE & SIMIP \\
\hline 14 & SIMIP & SIMIP & PAINI & $\Delta \Lambda \mathrm{I}$ \\
\hline 15 & $\Delta N=I$ & $\Delta I N I$ & 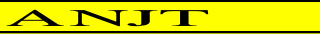 & $\Delta I J I$ \\
\hline
\end{tabular}

Sumber; data olahan

Tabel 7 diatas, yang berwarna hijau menunjukkan tidak bangkrut, warna abu-abu menunjukkan tidak di ketahui apakah sedang bangkrut atau tidak, dan yang berwarna kuning menunjukkan perusahaan mengalami tekanan keuangan (financial distress) atau bangkrut, dapat diketahui bahwa pada tahun 2014, berdasarkan kelompok saham perusahaan sub sektor perkebunan yang mempunyai kinerja paling baik 
berdasarkan model Tobin's $q$ untuk pertumbuhan investasi adalah dengan kode emiten SSMS, LSIP dan BWPT. Pada tahun 2015, kelompok saham perusahaan sub sektor perkebunan yang mempunyai kinerja paling baik adalah SSMS dan BWPT dan pada tahun 2016 kelompok saham perusahaan sub sektor perkebunan yang mempunyai kinerja paling baik adalah SSMS dan LSIP. Pada tahun 2017, kelompok saham perusahaan sub sektor perkebunan yang mempunyai kinerja paling baik adalah SSMS, BWPT, UNSP dan JAWA. Sedangkan berikut merupakan ringkasan keseluruhan kinerja perusahaan berdasarkan kelompok saham sub sektor perkebunan yang mempunyai kinerja paling baik berdasarkan model Tobin's $q$ seperti pada tabel berikut;

\section{Tabel 8}

Kinerja perusahaan berdasarkan model Altman Z-score Pertama, Revisi dan Modifikasi pada Sub Sektor Perkebunan di BEI periode 2014-2017.

\begin{tabular}{|c|c|c|c|c|c|c|c|c|c|c|c|c|}
\hline & \multicolumn{4}{|c|}{ Kode Model Altman Z-score Pertama } & \multicolumn{4}{|c|}{ Kode Model Altman Z-score Revisi } & \multicolumn{4}{|c|}{ Kode Model Altman Z-score Modifikasi } \\
\hline No & 2014 & 2015 & 2016 & 2017 & 2014 & 2015 & 2016 & 2017 & 2014 & 2015 & 2016 & 2017 \\
\hline 1 & SSMS & SSMS & SSMS & LSIP & LSIP & LSIP & LSIP & LSIP & LSIP & LSIP & LSIP & LSIP \\
\hline 2 & LSIP & LSIP & LSIP & SSMS & ANJT & SMAR & AALI & AALI & SSMS & ANJT & AALI & AALI \\
\hline 3 & AALI & AALI & AALI & AALI & SSMS & ANJT & SMAR & ANJT & ANJT & AALI & ANJT & ANJT \\
\hline 4 & SMAR & SMAR & SMAR & SMAR & AALI & AALI & ANJT & SMAR & AALI & SSMS & PALM & SSMS \\
\hline 5 & DSNG & DSNG & ANJT & ANJT & SMAR & SSMS & SSMS & DSNG & SGRO & SGRO & SSMS & SMAR \\
\hline 6 & ANJT & SGRO & SIMP & DSNG & SGRO & SGRO & PALM & SSMS & GOLL & SIMP & SMAR & SGRO \\
\hline 7 & SGRO & ANJT & TBLA & TBLA & TBLA & SIMP & SIMP & SIMP & SIMP & DSNG & SIMP & SIMP \\
\hline 8 & TBLA & TBLA & SGRO & SGRO & DSNG & DSNG & SGRO & SGRO & SMAR & GZCO & SGRO & DSNG \\
\hline 9 & SIMP & SIMP & DSNG & SIMP & SIMP & TBLA & TBLA & TBLA & DSNG & TBLA & TBLA & TBLA \\
\hline 10 & BWPT & BWPT & PALM & BWPT & GZCO & GZCO & DSNG & PALM & TBLA & SMAR & DSNG & PALM \\
\hline 11 & GZCO & GZCO & BWPT & PALM & JAWA & JAWA & GOLL & BWPT & GZCO & GOLL & GOLL & BWPT \\
\hline 12 & JAWA & JAWA & GOLL & GZCO & GOLL & GOLL & BWPT & GOLL & JAWA & JAWA & BWPT & GZCO \\
\hline 13 & GOLL & GOLL & JAWA & GOLL & PALM & BWPT & JAWA & GZCO & PALM & BWPT & JAWA & GOLL \\
\hline 14 & PALM & PALM & GZCO & JAWA & BWPT & PALM & UNSP & JAWA & BWPT & PALM & GZCO & JAWA \\
\hline 15 & UNSP & UNSP & UNSP & UNSP & UNSP & UNSP & GZCO & UNSP & UNSP & UNSP & UNSP & UNSP \\
\hline
\end{tabular}

Sumber; data olahan

Tabel 8 diatas, dapat diketahui bahwa kinerja saham Model Altman Z-score Pertama, yakni pada tahun 2014, berdasarkan kelompok saham perusahaan sub sektor perkebunan yang mempunyai kinerja paling baik berdasarkan model Altman Z-score Pertama untuk potensi kebangkrutan adalah dengan kode emiten SSMS, LSIP dan AALI. Pada tahun 2015, 2016 dan 2017 yang mempunyai kinerja paling baik adalah SSMS dan LSIP. Berdasarkan kinerja saham Model Altman Z-score Revisi, yakni pada tahun 2014, berdasarkan kelompok saham perusahaan sub sektor perkebunan yang mempunyai kinerja paling baik berdasarkan model Altman Z-score Revisi untuk potensi kebangkrutan adalah dengan kode emiten LSIP, ANJT dan SSMS. Pada tahun 2015, 2016 dan 2017 yang mempunyai kinerja paling baik adalah LSIP.

\section{SIMPULAN}

Berdasarkan kinerja saham Model Altman Z-score Modifikasi bahwa pada tahun 2014, berdasarkan kelompok saham perusahaan sub sektor perkebunan yang mempunyai kinerja paling baik berdasarkan model Altman Z-score Modifikasi untuk potensi kebangkrutan adalah dengan kode emiten LSIP, SSMS, ANJT, AALI, SGRO dan GOLL. Pada tahun 2015, saham yang mempunyai kinerja paling baik yakni LSIP, ANJT, AALI dan SSMS. Pada tahun 2016, saham yang mempunyai kinerja paling baik yakni LSIP, AALI, ANJT, PALM, SSMS, SMAR dan SIMP dan tahun 2017 yang mempunyai kinerja paling baik adalah LSIP, AALI, ANJT, SSMS dan SMAR.

\section{DAFTAR PUSTAKA}

Adisetiawan, R., 2018, Does Stock Split Influence to Liquidity and Stock Return? (Empirical Evidence in the Indonesian Capital), Asian Economic and Financial Review, 8(5), 682-690

Adisetiawan, R., 2017, Globalisasi Pasar Modal Dunia dan Pengaruhnya Terhadap Pasar Modal Indonesia, Ekonomis: Journal of Ekonomics and Business, 1(1), 10-17 
Ahmadi, dan Alhudhori. M., 2017, Pengaruh Total Asset Turnover (TATO) dan Return on Equty (ROE) Terhadap Harga Saham pada Industri Asuransi di Bursa Efek Indonesia (BEI) Periode 2010-2014, EKSIS: Jurnal Ilmiah Ekonomi dan Bisnis, 6(2), 58-66

Ayu Suci Ramdhani dan Niki Lukviarman, 2009, Perbandingan Analisis Model Kebangkrutan Menggunakan Model Altman Pertama, Altman Revisi Dan Altman Modifikasi Dengan Ukuran Dan Umur Perusahaan Sebagai Variabel Penjelas (Studi Pada Perusahaan Manufaktur Yang Terdaftar Di Bursa Efek Indonesia).

Bambang Sudiyatno dan Elen Puspitasari, 2010, Tobin,s q dan Altman's Z-score sebagai indikator pengukuran kinerja perusahaan.

Fahmi, Irham. 2013, Pengantar Manajemen Keuangan, Teori Soal dan Jawab, Bandung: Alfabeta

Hikam Lazuardy, 2016, Analisis Pengukuran Kinerja Keuangan Dengan Model Altman Z-Score dan Tobin's Q. Studi Kasus Pada Perusahaan Sektor Makanan Dan Minuman Di BEI Periode 2010-2014.

Kokyung dan Siti Khairani, 2014, Analisis Penggunaan Altman Z-score dan Springate untuk Mengetahui Potensi Kebangkrutan pada PT.Bakrie Telecom, STIE, MDP.

Platt, H., dan M. B. Platt. 2002, Predicting Financial Distress, Journal of Financial Service Professionals. Sjahrial, Dermawan. 2014, Manajemen Keuangan Lanjutan, Edisi revisi Jakarta:Mitra Wacana Media Tandelilin,E., 2001, Analisis Investasi dan Manajemen Portofolio, Edisi Pertama, Penerbit BPFE, Yogyakarta. 